\title{
Effects of Aluminum Sulfate on Some Maternal Variables in Pregnant Mice
}

\author{
*Mamoona Nasim \\ Dept. of Basic Medical and Dental Sciences, Princess Nourah Bint Abdulrehman University, Saudi Arabia
}

Submission: February 26, 2017; Published: March 10, 2017

*Corresponding author: Mamoona Nasim, Chair of Dept. of Basic Medical and Dental Sciences, College of Dentistry, Princess Nourah Bint Abdulrehman University, KSA, Saudi Arabia, Email: mamoona_nasim@yahoo.com

\begin{abstract}
Present study was carried out to determine the effects of aluminum sulfate on pregnant mothers. The duration of exposure was correlated with the effects on physical activity and their weight gains throughout gestation. Seventy-two pregnant mice were given a daily intraperitoneal dose of $0.7 \mathrm{mg} / 100 \mathrm{~g}$ of aluminum sulphate for various periods according to the grouping of experimental design. This dose was equivalent to maximum therapeutic dose of aluminum salt for a $70 \mathrm{~kg}$ man i.e. $5000 \mathrm{mg}$ aluminum/day. Mice were observed for physical activity at 09 : am and then at 05: pm. Animals was sacrificed on day 20 of gestation. The number of live and dead fetuses in the treated animals was not significantly different from the control groups. Therefore embryo lethality of aluminum could be concluded. However there was an overall negative effect of aluminum observed on maternal body weight gain during gestation. Though significant effect on body weight was only observed in animals treated with the aluminum for longer duration. The effects of aluminum were also detected on gravid uterine weight, corrected body weight (body weight at sacrifice minus gravid uterine weight), corrected body weight change, and kidney weight.
\end{abstract}

Keywords: Aluminum; Gestation; gravid uterine weight; corrected body weight

\section{Introduction}

The earth's surface is abundant in aluminum compounds and there is a growing realization that excessive exposure to aluminum can produce aluminum accumulation and toxic syndromes under certain conditions [1]. Use of aluminum saucepans, aluminum-lined cooking utensils and containers may increase the content of aluminum in food. This is particularly true when acidic food stuffs are stored in aluminum utensils. Rhubarb cooked in an aluminum saucepan contained $25 \mathrm{mg}$ per portion compared to $0.1 \mathrm{mg}$ aluminum per portion if rhubarb is cooked in a stainless steel saucepan. Normally, the addition of aluminum to the diet from cooking utensils is minimal and has been assumed to have no toxicological significance. Daily intake of aluminum containing antacids could increase approximately 100 times the normal intake from food- stuffs. Daily doses of several grams of aluminum are not unusual in individuals using antacids. There is sufficient evidence to suggest that maternal intoxication with lead, cadmium and mercury, both in man and laboratory animals may adversely affect health of pregnant mothers and the development of conceptus [2].

Elevated aluminum has been implicated for years in Alzheimer's and Parkinson's diseases which characterize extreme memory loss, absent-mindedness, or dementia respectively. It is sometimes found in the hair of children diagnosed with ADHD (Attention Deficit Hyperactivity Disorder), ADD (attention deficit disorder), and those with seizures. Hyperactivity, memory disturbances, and learning disabilities may result from even mildly elevated levels of aluminum also. It is reported to produce inhibition of neurotransmission and impaired motor coordination [3].

Aluminum is widely distributed in nature. It is found in both organic and inorganic forms in vegetation and in all vertebrate species. Its level depends upon the geochemistry of local environment. In municipal water supplies slightly higher levels are found because it's salt with sulfates are used during water purification procedures. With more awareness of spread of water borne illnesses, it is a routine now especially in urban areas of Pakistan to use treated water instead of fresh surface/ ground water. During surface water treatment, alum (aluminum sulphate) is normally added as a coagulant to assist in the removal of turbidity, which results in the reduction of pathogenic microorganisms, such as viruses and Giardia. Coagulation also reduces the formation of disinfection by-products by removing organic material prior to disinfection [4]. 
Its wide distribution in nature and increasing use of this metal for cooking utensils from which small amounts may be dissolved by the food, especially in the presence of alkalis and sodium chloride has stimulated various researches to investigate about its occurrence in food and influences on animals, plants and human beings. Daily dietary intake of aluminum varies from country to country because of wide variation in the dietary habits of individuals of various countries. An average European or American adult consumes 20-30 mg aluminum daily in foods and beverages. In these countries high dietary aluminum content is because of common use of aluminum containing food additives, food dyes and colors, in preparation of baked, processed and canned foods [5]. In African and Asian countries e.g. Pakistan, the major source of dietary aluminum is cooking utensils. It has been found that most foods stored or cooked in aluminum pans, trays or foils accumulate some aluminum. Aluminum content of foods cooked or baked in aluminum utensils depends upon various factors such as $\mathrm{pH}$ length of cooking period, usage of new pans or pressure cooker etc. So 2-3mg of aluminum may be ingested daily from a normal routine diet. As a rule $6 \mathrm{mg} /$ day is considered as an average daily intake of aluminum in diet [5].

As the aluminum is abundantly present in earth's crest, humans are continuously exposed to this element. The lungs, skin and gastrointestinal tract are major barriers to aluminum absorption, which is limited to only few micrograms per day. The small amount of aluminum that is absorbed from the body is readily eliminated from the body by the kidneys. Thus in healthy individual, under normal circumstances, with normal exposure, there is little evidence that aluminum offers any risk to the organism. However absorption barriers can be overcome when large doses of aluminum are given orally in the form of antacids or when aluminum is given parenteraly [6].

In the body it has a number of biological effects. It promotes the reaction between cytochrome $\mathrm{c}$ and succinic delydrogaose and is a necessary co-factor for the acceleration of guanine nucleotide binding protein by fluoride for the stimulation of adenylate cyclase activity. It has an inhibitory effect on bone-phosphates, hexokinases and enhances the activity of cholinesterase. Aluminum has also been shown to displace magnesium from ATP. The resulting stabilization of ATP prevents phosphate transfer by $\mathrm{Na}+\mathrm{K}+$-ATPase. It also binds calmodulin and inhibits ferroxidase (ceruloplasmin) activity [7].

Apart from its important biological action, it has a number of syndromes which are affiliated with its high level (Toxicity) e.g. Alzheimer disease. Amyotrophic lateral sclerosis and Parkinsonian dementia of Guamn [8]. In experimental animals it has also been found to be nephrotoxic [9]. Aluminum salts administered by different routes can produce toxic effects in animal models. Some of which involve alterations in enzymatic activities. It is presently accepted that aluminum intoxication may induce anemia and encephalopathy in humans and animals .Kaiser and Schwartz proposed that aluminum may cause microcytic anemia by a direct effect on heme biosynthesis.
Several research studies have reported an increase in risk of developmental/growth defects associated with high aluminum intake during pregnancy .All these studies have pointed out towards a true association between high aluminum intake during pregnancy and pre and postnatal birth defects. Therefore, to minimize any potential risk from residual aluminum in water treated with aluminum-based coagulants, water treatment processes should be optimized in order to reduce residual aluminum levels to the lowest extent possible. Secondly, proper documentation of guideline prepared after experimental measurements of optimum level of aluminum is required $[10,11]$.

According to a report by Dórea JG and, Marques RC [12], human breast milk contained 5-20 micrograms per liter of aluminum, cow's milk-based formulae contained 20 times more aluminum, and soy-based formulas contained even 100 times more of the metal. Thus it was established that human breast milk have the lowest concentration of aluminum and is the safest feed. Generally speaking, heavy metals produce adverse effects by disrupting metabolic function in different ways:

a. These accumulate in the heart, brain, kidneys, bone, liver and gastrointestinal tract and derange their functions.

b. These displace vital nutritional minerals from their normal internal environment. For example, enzymes act as catalysts for practically every biochemical reaction in all lifesustaining processes of metabolism, and if lead or aluminum replaces calcium of the enzymes it will become toxic and disruptive in its properties.

Aluminum was thought to be nontoxic in the past. However, recent data have raised serious questions about the hazards of this metal. As the possible health effects are not well defined and, there are insufficient data at present to support setting a health-based guideline. A metal which appears harmless today may prove to cause damage to the future generations. Therefore, the current investigations are designed to find the role of aluminum-containing compounds in producing harmful effects during pregnancy.

\section{Materials and Methods}

Albino mice were purchased from Veterinary Research Institute, Lahore and were kept in 1829 13-cm mouse cages in Postgraduate Medical Institute, Lahore. The housing and treatments of animals were in accordance with our national and institutional guidelines and all procedures were approved by the University of Health Sciences, Lahore. Animals were fed commercially prepared chick feed No.3. Water was provided ad lib in glass bottles. Care was taken regarding maintenance of optimum light and temperature in animal room. Rooms were maintained at $25 \pm 2{ }^{\circ} \mathrm{C}$ under a 12 :12-hour light: dark (L:D) cycle, with the lights on at 10.00 hour. Prior to the start of the experiment, animals were kept for a couple of weeks without 
treatment to allow them to adjust to the new environment, and to exclude any already pregnant female.

Seventy two adult (12-16 weeks old) virgin Albino female mice and thirty six male were used for the present study. Virgin female mice were time-mated by being placed into the cage of a male for 4 hour beginning at 0800 hour (at the end of the dark phase of the L: D cycle). Mating was allowed during the estrus period. The stage of estrus cycle was detected by using the following parameters.

a.Dryness and bluish discoloration of superficial genitalia of female mice as one of the earliest signs of heat.

b.Positive Ear quivering test showed that the animal was in heat.

Table 1: Experimental Design.

\begin{tabular}{|c|c|c|c|c|c|}
\hline Control & & & Experimental & & \\
\hline Group & Dose & Period* & Group & Dose & Period* \\
\hline \multirow[t]{3}{*}{$\mathrm{A}$} & $0,25 \mathrm{ml}$ of & $1-6$ & A1 & $0.25 \mathrm{ml}$ of & $1-6$ \\
\hline & distilled water & & & $\mathrm{Al} 2(\mathrm{SO} 4) 3$ & \\
\hline & & & & solution & \\
\hline $\mathrm{B}$ & -do- & $7-12$ & B1 & -do- & $7-12$ \\
\hline $\mathrm{C}$ & -do- & $13-18$ & $\mathrm{C} 1$ & -do- & $13-18$ \\
\hline $\mathrm{D}$ & -do- & $1-12$ & D1 & -do- & $1-12$ \\
\hline $\mathrm{E}$ & -do- & $7-18$ & E1 & -do- & $7-18$ \\
\hline $\mathrm{F}$ & -do- & $1-18$ & $\mathrm{~F} 1$ & -do- & $1-18$ \\
\hline
\end{tabular}

\section{Data Collection}

During the period of gestation, maternal body weights were recorded on 6, 13 \& 18pcd (post coital day). On gestational Day 20, all animals were euthanized with diethyl ether, and the number of total implants, and live and dead fetuses were recorded. The two horns of uteri containing the embryos were dissected out and weighed. The weight of both kidneys was recorded with the help of electric scale. The Relative Tissue Weight Index for kidneys was calculated by using the following formula [13].

Mean weight of tissue x 100

RTWI =

Mean body weight

\section{Statistical Data Analysis}

Software SPSS for Windows (version 13) was employed for statistical analysis of data. With the help of independent t-test, one-way analysis of variance (ANOVA) followed by the Tukey HSD test with level of significance set at $\mathrm{P}<0.05$ to determine the differences between the control and experimental groups. All data are presented as mean \pm SD. Standard Error (SE) were estimated for each case. All comparisons between control and experimental groups were performed using post hoc analyses with the Tukey method for multiple comparisons. Significance was set at the 0.05 probability level.
Vaginal smear study was not done to avoid pseudo pregnancy. Mating was verified by the presence of a vaginal plug (day 0 of gestation). Mice with sperm plug were weighed and housed three per cage. Pregnant dams of comparable weight were divided into six groups; all dams were treated identically, with food and water ad lib. The animals were weighed and average weight was found to be $30 \mathrm{gm}$ on day 1 of pregnancy.

\section{Experimental Design}

Pregnant female mice were divided at random into various control and experimental groups, labeled and given intraperitoneal injections of distilled water and drug respectively (Table 1).

*Days of gestation.
Results

The weight gain of the mothers of experimental groups was very slow as compared to control groups. When administered for shorter periods compound did not produce any sign and symptom of toxicity in the mothers. But when used for long time e.g. mothers of F1 group. Out of six mothers only 3 survived and all of them were listless, weak and exhausted on day 20 of pregnancy.

Mothers of group A1, B1and C1 did not show any noticeable toxic effects of salt in the form of cholinergic signs. Differences between groups in maternal behaviors were mainly observed in mice given prolonged exposures. Only 2 mothers of group B1 and 3 of group C1 did show some increased respiratory activity and decreased locomotor activity during that particular period of dose administration. All those toxic symptoms disappeared within 24 hours of stoppage of drug. All the 6 mothers of each group survived till day 20 of pregnancy.

A similar dose of Al2 (SO4)3 when used for longer periods i.e. in groups D1 and E1, did show toxicity regarding physical activities of mothers. In group E1 five out of six mothers survived till day 20 of pregnancy. Still longer periods of dose administration as done in group F1 showed severe toxic symptoms in all the mothers and only three out of six were able to survive from these acute toxic effects. 
The signs which appeared in mothers of group D1, E1, and F1, have strongly indicated toxicity of aluminum sulphate. Recovery of mothers from these toxic effects was $100 \%$ in group D1, $90 \%$ in group E1, and only 50\% in group F1. The most striking finding of the current investigation is reduced vascularity of site of implantations in mothers of group F1 (Figures $1 \& 2$ ).
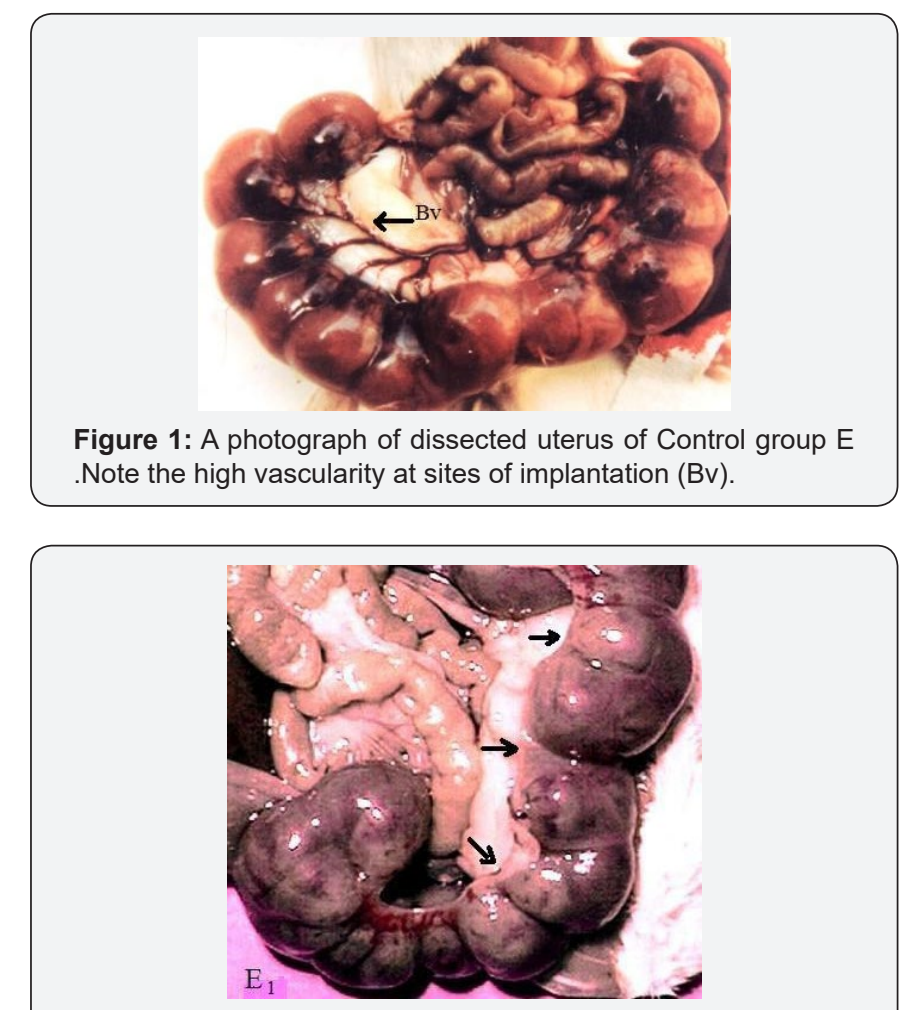

Figure 2: A photograph of dissected uterus of Experimental group E1 (Note the reduced vascularity of experimental uterus at the sites of implantations (black Arrows).

Following observations were made after salt administration in mothers of experimental group D1, E1 and F1.

Motor Activity and Grip Strength: One of the important signs of toxicity was immobility. Mice stopped walking and remained fixed in one spot, sitting hunched with eyes open. As time progressed mice assumed a flattened posture with head extended and hind legs protruding; this posture reflected

Table2: Effects of Aluminum Sulphate on Some Maternal Variables in Pregnant Mice.

\begin{tabular}{|c|c|c|c|c|c|c|}
\hline $\begin{array}{c}\text { Maternal } \\
\text { Parameters }\end{array}$ & Control & A1 & B1 & C1 & D1 & F1 \\
\hline $\begin{array}{c}\text { Average mother } \\
\text { weight (g) at } \\
\text { day 0 }\end{array}$ & 30.45 & 30.5 & 30.2 & 30.4 & 30.3 \\
\hline $\begin{array}{c}\text { Number of } \\
\text { Implants }\end{array}$ & 10 & 11 & 10 & 10 & 10 \\
\hline $\begin{array}{c}\text { Number } \\
\text { of Fetuses } \\
\text { Recovered }\end{array}$ & 10 & 10 & 9 & 10 & 9 \\
\hline $\begin{array}{c}\text { Kidney weight } \\
\text { (g) at day 20 }\end{array}$ & 0.387 & 0.383 & 0.387 & 0.384 & 9 \\
\hline
\end{tabular}




\section{Anatomy Physiology \& Biochemistry International Journal}

\begin{tabular}{|c|c|c|c|c|c|c|c|}
\hline $\begin{array}{c}\text { Total mother } \\
\text { weight at day } \\
20\end{array}$ & 52.07 & 52.24 & 50.36 & 51.39 & 50.55 & 50.89 & 49.20 \\
\hline $\begin{array}{c}\text { Net increase in } \\
\text { body weight }\end{array}$ & 21.62 & 21.74 & 20.16 & 20.99 & 19.75 & 20.59 & 18.70 \\
\hline
\end{tabular}

Comparison of Average of Different Control and Experimental groups. The results of the current study show that aluminum administration to pregnant mice at doses of $0.7 \mathrm{mg} / 100 \mathrm{~g} \mathrm{B.W}$. of Aluminum sulphate/day has adverse maternal effects that are evidenced by a significant reduction in body weight gain on Days $6,12 \& 18$. The reduction in body weight was associated with reduction in, gravid uterine weight and corrected body weight. These change were not only in relation to the control groups, but also in comparison with the groups given aluminum for only one week (group A1, B1, C 1) or two weeks (group D1 \& E1). However, no significant differences between the groups exposed to aluminum for one week only, could be noted.

With regard to aluminum-induced developmental toxicity, adverse effects were observed at $0.7 \mathrm{mg} / 100 \mathrm{~g}$ B.W. of Aluminum sulphate/day given for two weeks. These effects were significantly more notable when aluminum was administered for full gestational period i.e. three weeks (group F1). Although corrected body weight change was also lower in the groups exposed to aluminum for one week only (group A1, B1, C1) the differences between these groups did not reach the level of statistical significance $(\mathrm{P}>0.05)$.

Significant differences in the number of live fetuses per litter, percentage of post-implantation loss, fetal body weight, and the number of litters with reduced CR Length were also observed between these groups. In addition, significant differences between the groups exposed for one week only and the groups exposed to this dose of aluminum for longer periods were also found in maternal weight gain, body weight at termination, gravid uterine weight, and corrected body weight.

Effect of duration and time of gestational exposure on intrauterine growth and development of mice was tested for significance using t-test and ANOVA. Tukey honesty significance

Table 3: Statistical Analysis of Kidney Weight of mice.

\begin{tabular}{|c|c|c|c|c|c|c|}
\hline \multirow{2}{*}{ Groups } & Control** & Experimental** & $\begin{array}{c}\text { Mean } \\
\text { Difference }\end{array}$ & $\begin{array}{c}\text { Std. Error } \\
\text { Difference }\end{array}$ & t-Score & p-value \\
\hline A/A1 & $0.3875 \pm 0.009$ & $0.3828 \pm 0.009$ & 0.005 & 0.0054 & 0.861 & 0.410 \\
\hline B/B1 & $0.3945 \pm 0.006$ & $0.3868 \pm 0.009$ & 0.008 & 0.0044 & 1.746 & 0.111 \\
\hline C/C1 & $0.3940 \pm 0.010$ & $0.3843 \pm 0.011$ & 0.010 & 0.0063 & 1.539 & 0.155 \\
\hline D/D1 & $0.3725 \pm 0.019$ & $0.3300 \pm 0.037$ & 0.043 & 0.0170 & 2.506 & $0.031^{*}$ \\
\hline E/E1 & $0.3820 \pm 0.020$ & $0.3350 \pm 0.013$ & 0.047 & 0.0105 & 4.473 & $0.002^{*}$ \\
\hline F/F1 & $0.3892 \pm 0.010$ & $0.3073 \pm 0.007$ & 0.082 & 0.0065 & 12.654 & $0.000^{*}$ \\
\hline & & $*$
\end{tabular}

differences were used as post-hoc test to firm up the results. It is a single-step multiple comparison statistical procedure to find which means are significantly different from one another. It compares all possible pairs of means. The observation being tested should be independent. Levene test of homogeneity of variance was performed to find the normality of the data. Relative tissue index (\%) was calculated for kidney and liver of mice in experimental and control groups and effect of this parameter was analyzed statistically.

\section{Effects on Maternal Kidneys}

In all the control and experimental groups, there was no difference in the apparent size of the kidneys. However, kidneys of control group mothers had a rich, brownish red color and were firm in consistency. Cortex was "dotted" looking. Kidneys of treated group mothers were softer in consistency and darker in color.

The analysis of kidney weight related differences among different duration and time of gestational exposure was calculated using the independent sample t-test between the corresponding experimental and control group. Table 3 shows that effect on group A1, B1, and C1 are insignificant while on group D1, E1 and F1 it is significant. ANOVA showed that there is insignificant effect on the kidney weight on group A1, B1 and C1 and significant effects on group D1, E1 and F1. Post Hoc test using the Tukey HSD also showed that difference in the mean weights of kidney among groups D1, E1 and F1 are statistically significant $(\mathrm{P}<0.05)$ (Table 4). Relative tissue weight index $(\%)$ of kidney of control and experimental groups were calculated. T-test indicated that their differences are significant at $\mathrm{p}<0.05$ (Table 5). Fig 5 presents line chart showing decrease in kidney weight of mice in different groups (Tables $3 \& 5$ ).

* Statistically significant (p-value < 0.05) (Figure 4). 


\section{Anatomy Physiology \& Biochemistry International Journal}

Table 4: Post Hoc test using the Tukey HSD.

\begin{tabular}{|c|c|c|c|c|}
\hline \multirow{2}{*}{ Control (I) } & Experimental (J) & Mean Difference (I-J) & Std. Error (SE) & $\begin{array}{c}\text { Level of } \\
\text { Significance } \\
\text { (p-value) }\end{array}$ \\
\hline Control & A1 & 0.0040 & 0.0100 & 0.9996 \\
\hline & B1 & 0.0000 & 0.0100 & 1.0000 \\
\hline & C1 & 0.0025 & 0.0100 & $0.0001^{*}$ \\
\hline & D1 & 0.0568 & 0.0100 & $0.0004^{*}$ \\
\hline
\end{tabular}

Table 5: Relative Tissue Weight Index (\%) of Kidney.

\begin{tabular}{|c|c|c|c|c|c|c|}
\hline Groups & Control & Experimental & Mean & $\begin{array}{c}\text { Std. Error } \\
\text { Difference }\end{array}$ & t-Score & p-value \\
\hline A/A1 & 0.738 & 0.733 & 0.0053 & & 1.752 & $0.0452^{*}$ \\
\hline B/B1 & 0.764 & 0.768 & -0.0043 & 0.0258 & & \\
\hline C/C1 & 0.761 & 0.748 & 0.0132 & & & \\
\hline D/D1 & 0.705 & 0.653 & 0.0519 & & & \\
\hline E/E1 & 0.736 & 0.658 & 0.0775 & & & \\
\hline F/F1 & 0.752 & 0.625 & 0.1274 & & & \\
\hline
\end{tabular}

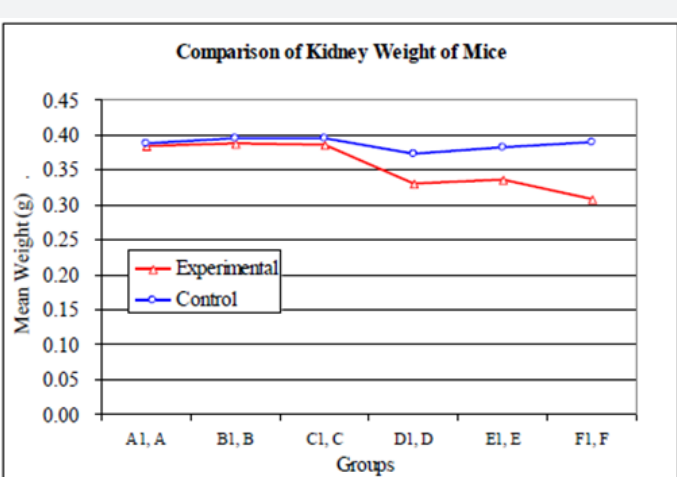

Figure 4: Line graph showing decrease in kidney weight in experimental group.

\section{Conclusion}

The results of the present study indicate that aluminum sulfate has adverse effects on mothers if they are exposed to this metal throughout gestation.

\section{References}

1. Krewski D, Yokel RA, Nieboer E, David B, Cohen J, et al (2007) Human Health Risk Assessment for Aluminium, Aluminium Oxide, and Aluminium Hydroxide. J Toxicol Environ Health B Crit Rev 10(Suppl 1): $1-269$.

2. Bellés M, Albina ML, Sanchez DJ, Corbella J, Domingo JL (2001) Effects of oral aluminum on essential trace elements metabolism during pregnancy. Biol Trace Elem Res 79(1): 67-81.

3. El-Rahman SS (2003) Neuropathology of aluminum toxicity in rats (glutamate and GABA impairment). Pharmacol Res 47(3): 189-194.
4. Kobe University (2016) Tracking aluminum used to purify tap water. Science Daily.

5. Sato K, Suzuki I, Kubota H, Furusho N, Inoue T, et al. (2014) Estimation of daily aluminum intake in Japan based on food consumption inspection results: impact of food additives. Food Sci Nutr 2(4): 389397.

6. Schafer U, Seifert M (2006) Oral intake of aluminum from foodstuffs, food additives, food packaging, cookware and pharmaceutical preparations with respect to dietary regulations. Trace Elements and Electrolytes. 23(7): 150-161.

7. D Haese PC (2013) Aluminum, Biological Effects. Encyclopedia of Metallo proteins, Springer 47-53.

8. Tomljenovic L (2011) Aluminum and Alzheimer's disease: after a century of controversy, is

there a plausible link? J Alzheimer's Dis 23(4): 567-598.

9. Edalat-Nejad M, Ghasemikhah R, Delavar M (2014) Aluminum overload: still as a source of concern in hemodialysis patients. Saudi J Kidney Dis Transpl 25(2): 412-414.

10. Osińska E, Kanoniuk D, Kusiak A (2004) Aluminum hemotoxicity mechanisms. Ann Univ Mariae Curie Sklodowska Med 59(1): 411-416.

11. Colomina MT, Roig JL, Torrente M, Vicens P, Domingo JL (2005) Concurrent exposure to aluminum and stress during pregnancy in rats: Effects on postnatal development and behavior of the offspring. Neurotoxicol Teratol27(4): 565-574.

12. Dórea JG, Marques RC (2010) Infants' exposure to aluminum from vaccines and breast milk during the first 6 months. J Expo Sci Environ Epidemiol 20(7): 598-601.

13. Zahid A, Abidi TS (2002) Morphological and Histological Evaluation of Developing Kidney in Rats Exposed to Chloroquine. Proceeding Sheikh Zaid Post Graduate Medical Institute 16(1): 5-10. 
(C) This work is licensed under Creative (1) Commons Attribution 4.0 Licens BY DOI:10.19080/APBIJ.2017.01.555571

\section{Your next submission with Juniper Publishers} will reach you the below assets

- Quality Editorial service

- Swift Peer Review

- Reprints availability

- E-prints Service

- Manuscript Podcast for convenient understanding

- Global attainment for your research

- Manuscript accessibility in different formats ( Pdf, E-pub, Full Text, Audio)

- Unceasing customer service

Track the below URL for one-step submission https://juniperpublishers.com/online-submission.php 